\title{
WOOD AND CHARCOAL IDENTIFICATION OF FIVE SPECIES FROM THE MISCELLANEOUS GROUP KNOWN IN BRAZIL AS "Angelim" BY NEAR-IR AND WOOD ANATOMY
}

\author{
Graciela Inés Bolzon de Muñiz ${ }^{1}$, Mayara Elita Carneiro', \\ Francielli Rodrigues Ribeiro Batista ${ }^{2}$, Felipe Zatt Schardosin ${ }^{2}$, Silvana Nisgoski, ${ }^{1, \AA}$
}

\begin{abstract}
Samples of wood sold as "angelim" in Brazil were studied. Disks from the trunks of Diplotropis purpurea, Hymenolobium petraeum, Parkia pendula, Vatairea guianensis and Vatairea paraensis were obtained from Mato Grosso state. Samples from pith to bark of each species were obtained, oriented in the three anatomical planes. Each sample was wrapped in aluminum foil and carbonized in a muffle furnace, with a final temperature of $450{ }^{\circ} \mathrm{C}$ and a heating rate of $1,66{ }^{\circ} \mathrm{C} \mathrm{min}{ }^{-1}$. The description of the anatomical elements of wood and charcoal samples followed the orientations of the International Association of Wood Anatomists, on the basis of 25 readings regarding frequency and tangential diameter of the vessels and height and width of the rays in micrometers. Infrared analyses were performed with a Bruker Tensor 37 spectrophotometer equipped with an integrating sphere and operating in reflectance mode, with resolution of $4 \mathrm{~cm}^{-1}$ and a spectral range of 10000-4000 $\mathrm{cm}^{-1}$. The wood and charcoal samples were placed on top of integrating sphere and one spectrum was obtained from each surface, resulting in six spectra for each physical sample. The results of anatomical analysis showed that the qualitative characteristics of wood remained in charcoal, so the method can be applied for species discrimination. When comparing cell dimensions, we observed different behavior between species in the same carbonization process in function of cell wall thickness and parenchyma distribution. In infrared analysis, pretreatment influenced adequate discrimination of "angelim" species in wood and charcoal. Linear discriminant analysis based on PCA scores and the region between 4000-6200 $\mathrm{cm}^{-1}$ was more efficient. Near infrared analysis can be used for differentiation of wood and charcoal of "angelim" species.
\end{abstract}

Keywords: Carbonization, NIR spectroscopy, ray cells, species discrimination, wood vessels.

\section{INTRODUCTION}

Wood commerce is generally based on species' common names, often determined by external characteristics like color and shape. In Brazil, for example, the name "angelim" is applied to the genera Andira, Dinizia, Hymenolobium and Vatairea, which have different anatomical and technological properties (Ferreira et al. 2004). In turn, two species of the genus Bowdichia and four of Diplotropis are popularly called "sucupira" (Soares et al. 2014).

\footnotetext{
${ }^{1}$ Laboratório de Anatomia e Qualidade da Madeira, Departamento de Engenharia e Tecnologia Florestal, Universidade Federal do Paraná, Curitiba, PR, Brasil. graciela.ufpr@gmail.com

${ }^{2}$ Postgraduate Students in Forest Engineering at the Federal University of Paraná, Curitiba, PR, Brasil.

" Corresponding author: silvana.ufpr@gmail.com

Received: 21.08.2015 Accepted:16.05.2016
} 
Wood technological properties are species related, so when wood from different species is sold under the same common name, the final product may not have the same quality expected by consumers. The most widely used method for wood identification is based on visual properties and description of anatomical structures, but for many groups of species, this identification is rarely accurate to the species level, and in some cases, only the botanical family can be correctly identified (Gasson 2011).

When the analysis is based on carbonized material, the difficulty of species discrimination increases. Studies of charcoal identification based on anatomical structure have shown that the qualitative characteristics of wood remain in charcoal and the identification is possible when comparing with a wood database, but this requires time and anatomical knowledge of wood (Muñiz et al. 2012, Gonçalves et al. 2012, 2014). One alternative is the use of nondestructive techniques like infrared spectroscopy, with the information collected directly from material surface.

A review by Tsuchikawa and Schwanninger (2013) showed the application of near infrared for online monitoring in different industries to detect morphological, chemical, physical and mechanical properties of lignocellulosic materials. Studies by Pastore et al. (2011) and Braga et al. (2011) described the identification and differentiation of species similar to Swietenia macrophylla (CITES Appendix II). Near infrared studies for species identification include discrimination of samples of different geographic origins, and influence of sample granulometry and surface features (Sandak et al. 2011, Nisgoski et al. 2015a, Hwang et al. 2016). Additionally, different data pretreatment and classification methods can be employed (Tominaga 1999).

Some studies for wood species identification are based on analysis of increment cores, chips or powder (Adedipe et al. 2008, Russ et al. 2009, Casale et al. 2010, Sandak et al. 2011, Pastore et al. 2011, Braga et al. 2011). For carbonized material, near infrared spectrometry has been used to distinguish species (Davrieux et al. 2010, Nisgoski et al. 2015b) and carbonization processes (Monteiro et al. 2010).

Identification of wood or any other material by spectral data depends on classification and pattern recognition techniques. Principal component analysis (PCA) is an unsupervised pattern recognition technique usually applied as the first step in the detection of clusters in the collected data (Ciosek et al. 2005). The results provided by PCA can be further refined by supervised pattern recognition techniques. Soft independent modeling of class analogy (SIMCA) is a method of multivariate classification based on PCA modeling, performed for each class in the calibration set. It is especially suited when high within-class variability is possible (Bylesjo et al. 2006, Stumpe et al. 2012). NIR spectra analyzed by this technique have shown good results in classifying veneers contaminated by blue stain fungi for plywood production (Carneiro et al. 2013) and classifying thermally modified wood (Bächle et al. 2012).

Linear discriminant analysis (LDA) focuses on dissimilarity between classes and can be used when data are classified in symmetric structures (Tominaga 1999). PCA associated with linear discriminant analysis (PCA-LDA) is based on PCA scores and allows the discrimination of groups based on spectra. Pre-processing is important to eliminate noise and remove physical phenomena in the spectra in order to improve the subsequent multivariate regression, classification model or exploratory analysis (Rinnan et al. 2009). Derivatives can remove additive and multiplicative effects in the spectra, as well as baselines and linear trends. Savitzky-Golay derivation includes a smoothing step (Siesler et al. 2002). Multiplicative scatter correction (MSC) is a scatter-corrective pretreatment technique applied to reduce the variability between samples due to scattering and also to adjust for baseline shifts (Martens et al. 1983, Geladi et al. 1985).

The main objective of this paper is the discrimination of wood and charcoal from different species of "angelim" based on anatomical structure and near infrared analysis. Two other goals are to contribute to control of illegal logging, by providing information on carbonized wood, and to test the potential use of solid charcoal material in near infrared analysis. 


\section{MATERIALS AND METHODS}

The wood samples of the species Diplotropis purpurea (Rich.) Amshoff. - Fabaceae (sucupira), Hymenolobium petraeum Ducke - Fabaceae (angelim pedra), Parkia pendula (Willd.) Benth. Ex Walp.Mimosaceae (angelim saia), Vatairea guianensis Aubl. - Fabaceae (angelim cascudo) and Vatairea paraensis Ducke - Fabaceae (angelim amargo) came from the municipality of Nova Maringá, Mato Grosso state $\left(13^{\circ} 1^{\prime} 2^{\prime \prime} \mathrm{S}, 57^{\circ} 4^{\prime} 8^{\prime \prime} \mathrm{W}\right)$. The trees were cut in a natural forest and stem discs with thickness of about $80 \mathrm{~mm}$ were taken at breast height $(1,3 \mathrm{~m})$. Samples of each species from pith to bark were obtained, with dimensions of $20 \times 20 \times 50 \mathrm{~mm}$, oriented in the three anatomical planes. In function of disk diameter, the number of samples varied from 8-10 per species. The samples were air dried and remained in a climatic chamber at temperature of $20 \pm 3{ }^{\circ} \mathrm{C}$ and relative humidity of $65 \pm 1 \%$.

For charcoal production, each sample was wrapped in aluminum foil and carbonized in a muffle furnace, with a final temperature of $450{ }^{\circ} \mathrm{C}$ and a heating rate of $1,66{ }^{\circ} \mathrm{C} \mathrm{min}{ }^{-1}$. The carbonized material remained at the final temperature for two hours. Aluminum foil was removed only for near infrared analysis.

The description of the anatomical elements of wood and charcoal samples followed the orientations of the International Association of Wood Anatomists (IAWA 1989), on the basis of 25 readings regarding frequency and tangential diameter of the vessels and height and width of the rays in micrometers. The images of the general distribution of the cells in the transversal plane were obtained with a stereomicroscope with digital camera (Zeiss Discovery V12). The cell dimensions of the wood and charcoal were compared by the Tukey test at a probability of $5 \%$.

Infrared analyses were performed with a Bruker Tensor 37 spectrophotometer (Bruker Optics, Ettlingen, Germany) equipped with an integrating sphere and operating in reflectance mode; 64 scans were averaged with resolution of $4 \mathrm{~cm}^{-1}$ and a spectral range of $10000-4000 \mathrm{~cm}^{-1}$. In a room with temperature of $23 \pm 2{ }^{\circ} \mathrm{C}$ and relative humidity of $60 \%$, the wood and charcoal samples were placed on top of the integrating sphere and one spectrum was obtained from each face (transversal, radial and tangential), resulting in a total of six separate spectra for each physical sample, for a total of 48-60 per species. Face measurement presented different spectral characteristics, so all spectra were used and named as a sample, without average. For analysis, we used 40 spectra of each species for calibration and the others (8-20) for classification testing.

The Unscrambler X chemometric program (version 10.1, from CAMO Software AS) was used to analyze the data. Exploratory modeling was done by analyzing the score and loading graphs obtained by principal component analysis (PCA) to verify possible differences in wood and charcoal. Individual models were based on the NIPALS algorithm and validated with cross validation. Second derivative of Savitzky-Golay (polynomial order $=2$, smoothing point $=3$ ) and multiplicative scatter correction (MSC) were applied to raw data. For MSC, the mean of the calibration set was used as the reference for the test set. SIMCA and PCA-LDA classifications were also performed. In the case of the SIMCA models, a maximum four PCs were used. LDA was calculated based on constant weight, through the quadratic method, assuming equal prior probabilities and using PCA scores projected for four components. Spectral analysis was based on ASTM E1655-05 (ASTM 2000). 


\section{RESULTS AND DISCUSSION}

\section{Wood and charcoal anatomy}

The micrographs of wood and charcoal samples, in transversal section (Figure 1), show the similar anatomical characteristics, such as diffuse pores, arranged in solitary and radial multiples, axial parenchyma lozenge-aliform and confluent, ray fine to medium, distinct. In charcoal, the more evident anatomical alterations caused by thermal degradation were vessel contraction and less distinction of parenchyma cells.

The qualitative characteristics of wood remained in charcoal. When comparing cell dimensions (Table 1), different behavior was observed: in Diplotropis purpurea, a decrease was observed in vessel diameter, ray height and ray width, and an increase in ray frequency; in Hymenolobium petraeum, frequency of vessels and rays and ray width increased; in Parkia pendula, a decrease was verified in vessel diameter and ray width; in Vatairea guianensis, a more significant increase in ray frequency (54\%) was observed; and in Vatairea paraensis, a significant decrease in vessel diameter (41\%) and increase in ray width $(43 \%)$ were present.

Similar differences have been reported in other studies, associated with the presence and distribution of parenchyma cells and fiber wall thickness (Muñiz et al. 2012, Gonçalves et al. 2012).

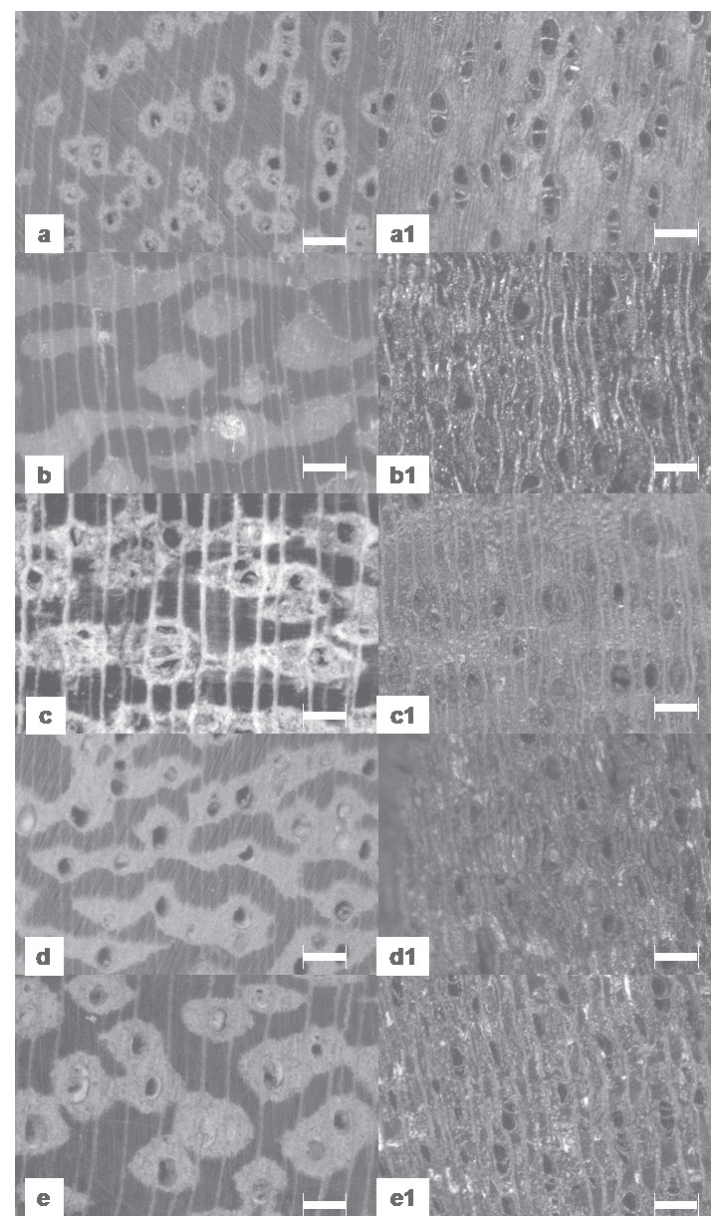

Figure 1. Transversal section of wood and charcoal from Diplotropis purpurea (a,a1), Hymenolobium petraeum (b,b1), Parkia pendula $(\mathrm{c}, \mathrm{c} 1)$, Vatairea guianensis (d,d1), Vatairea paraensis $(\mathrm{e}, \mathrm{e} 1)$. Scale bar $=500 \mu \mathrm{m}$. 
Table 1. Summary of changes in anatomical characteristics between wood and charcoal. Data are given as mean and standard deviation.

\begin{tabular}{|c|c|c|c|c|c|c|c|c|c|c|}
\hline \multirow[t]{2}{*}{ Species } & \multicolumn{2}{|c|}{$\begin{array}{c}\text { Vessel diameter } \\
(\mu \mathrm{m})\end{array}$} & \multicolumn{2}{|c|}{ Vessel $/ \mathbf{m m}^{2}$} & \multicolumn{2}{|c|}{ Ray height $(\mu \mathrm{m})$} & \multicolumn{2}{|c|}{$\begin{array}{c}\text { Ray width } \\
(\mu \mathrm{m})\end{array}$} & \multicolumn{2}{|c|}{ Rays/mm } \\
\hline & $\mathbf{W}$ & $\mathbf{C}$ & $\mathbf{W}$ & C & $\mathbf{W}$ & C & $\mathbf{W}$ & C & $\mathbf{W}$ & C \\
\hline $\begin{array}{l}\text { Diplotropis } \\
\text { purpurea }\end{array}$ & $\begin{array}{c}240,8 \mathrm{a} \\
(33,5)\end{array}$ & $\begin{array}{l}129,6 \mathrm{~b} \\
(39,4)\end{array}$ & $\begin{array}{r}4,4 \mathrm{a} \\
(1,6)\end{array}$ & $\begin{array}{r}5,4 \mathrm{a} \\
(2,2)\end{array}$ & $\begin{array}{l}467,6 \mathrm{a} \\
(128,9)\end{array}$ & $\begin{array}{l}292,3 b \\
(87,6)\end{array}$ & $\begin{array}{r}42,4 \mathrm{a} \\
(9,3)\end{array}$ & $\begin{array}{l}31,3 b \\
(7,2)\end{array}$ & $\begin{array}{r}5,4 \mathrm{a} \\
(1,1)\end{array}$ & $\begin{array}{l}7,1 \mathrm{~b} \\
(1,7)\end{array}$ \\
\hline $\begin{array}{l}\text { Hymenolobium } \\
\text { petraeum }\end{array}$ & $\begin{array}{l}222,4 a \\
(29,2)\end{array}$ & $\begin{array}{c}200,5 \mathrm{a} \\
(67,5)\end{array}$ & $\begin{array}{l}3,1 \mathrm{a} \\
(1,3)\end{array}$ & $\begin{array}{l}5,0 \mathrm{~b} \\
(1,9)\end{array}$ & $\begin{array}{l}353,7 \mathrm{a} \\
(110,4)\end{array}$ & $\begin{array}{c}361,2 \mathrm{a} \\
(80,1)\end{array}$ & $\begin{array}{c}33,0 \mathrm{a} \\
(9,8)\end{array}$ & $\begin{array}{c}42,5 b \\
(7,7)\end{array}$ & $\begin{array}{l}4,2 \mathrm{a} \\
(0,9)\end{array}$ & $\begin{array}{l}5,4 \mathrm{~b} \\
(1,5)\end{array}$ \\
\hline Parkia pendula & $\begin{array}{l}192,2 \mathrm{a} \\
(41,5)\end{array}$ & $\begin{array}{l}162,4 \mathrm{~b} \\
(54,1)\end{array}$ & $\begin{array}{l}2,6 \mathrm{a} \\
(1,1)\end{array}$ & $\begin{array}{l}3,4 \mathrm{~b} \\
(1,5)\end{array}$ & $\begin{array}{l}270,6 a \\
(100,4)\end{array}$ & $\begin{array}{l}300,5 \mathrm{a} \\
(90,8)\end{array}$ & $\begin{array}{r}51,4 \mathrm{a} \\
(12,3)\end{array}$ & $\begin{array}{l}44,7 \mathrm{~b} \\
(8,84)\end{array}$ & $\begin{array}{r}4,1 \mathrm{a} \\
(1,2)\end{array}$ & $\begin{array}{l}4,0 \mathrm{a} \\
(1,3)\end{array}$ \\
\hline $\begin{array}{l}\text { Vatairea } \\
\text { guianensis }\end{array}$ & $\begin{array}{c}187,2 \mathrm{a} \\
(34,3)\end{array}$ & $\begin{array}{l}159,3 b \\
(44,7)\end{array}$ & $\begin{array}{l}3,9 \mathrm{a} \\
(2,1)\end{array}$ & $\begin{array}{r}3,6 \mathrm{a} \\
(1,8)\end{array}$ & $\begin{array}{l}321,4 \mathrm{a} \\
(102,5)\end{array}$ & $\begin{array}{l}340,4 \mathrm{a} \\
(86,1)\end{array}$ & $\begin{array}{c}28,7 \mathrm{a} \\
(5,7)\end{array}$ & $\begin{array}{l}31,5 \mathrm{a} \\
(6,4)\end{array}$ & $\begin{array}{r}6,1 \mathrm{a} \\
(1,0)\end{array}$ & $\begin{array}{l}9,4 \mathrm{~b} \\
(1,5)\end{array}$ \\
\hline $\begin{array}{l}\text { Vatairea } \\
\text { paraensis }\end{array}$ & $\begin{array}{c}246,2 \mathrm{a} \\
(31,1)\end{array}$ & $\begin{array}{l}144,4 b \\
(30,9)\end{array}$ & $\begin{array}{r}3,2 \mathrm{a} \\
(1,3)\end{array}$ & $\begin{array}{l}3,8 \mathrm{a} \\
(2,0)\end{array}$ & $\begin{array}{l}509,0 \mathrm{a} \\
(210,9)\end{array}$ & $\begin{array}{l}463,4 a \\
(150,4)\end{array}$ & $\begin{array}{r}55,5 \mathrm{a} \\
(13,4)\end{array}$ & $\begin{array}{l}79,2 b \\
(21,2)\end{array}$ & $\begin{array}{r}3,6 \mathrm{a} \\
(0,8)\end{array}$ & $\begin{array}{l}4,6 \mathrm{a} \\
(1,1)\end{array}$ \\
\hline
\end{tabular}

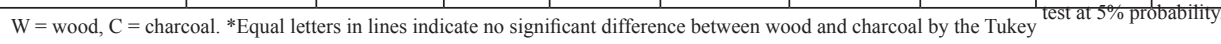

\section{NIR characteristics of wood and charcoal}

NIR spectra of "angelim" species are similar and some regions present more distinction between species in wood and in charcoal. In wood (Figure 2a), bands at $8749 \mathrm{~cm}^{-1}$ and $8547 \mathrm{~cm}^{-1}$ are related to aromatics of lignin; bands at $6800 \mathrm{~cm}^{-1}$ and $4401 \mathrm{~cm}^{-1}$ are attributed to hemicelluloses; regions near $6110-5697 \mathrm{~cm}^{-1}$ and $4335-4146 \mathrm{~cm}^{-1}$ are related to all cell wall components; the peak at $5200 \mathrm{~cm}^{-1}$ is from water, while that at $5995 \mathrm{~cm}^{-1}$ is related to extractives content (Tsuchikawa and Siesler 2003, Yonenobu and Tsuchikawa 2003, Schwaninger et al. 2011). In charcoal, small absorption was verified (Davrieux et al. 2010, Muñiz et al. 2013) and some irregularities in spectra were influenced by water $\mathrm{OH}$ bands (region near 7073-7181 and $5142 \mathrm{~cm}^{-1}$ ) and degradation of cell wall components (4335-4146 $\left.\mathrm{cm}^{-1}\right)$. 

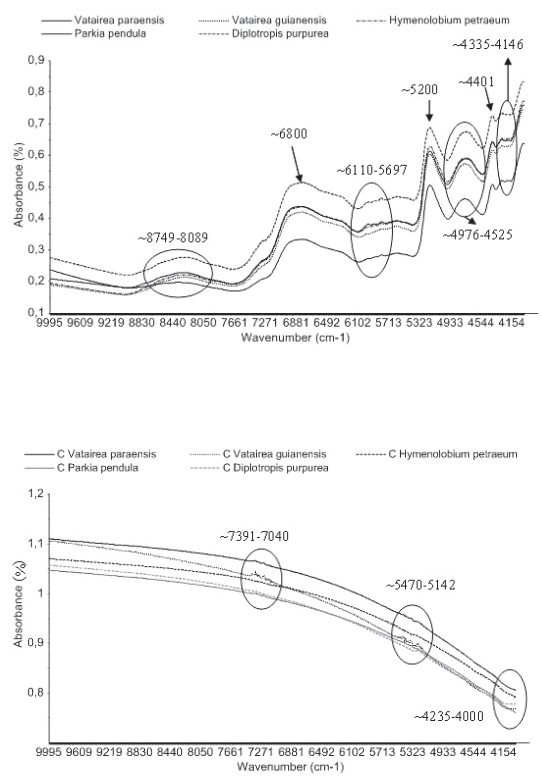

Figure 2. Mean spectra of wood and charcoal (C) samples of "angelim" species.

Second derivative eliminates baseline influence and shows the regions with most difference between wood and charcoal. All spectra by species were averaged and are compared in Figure 3.

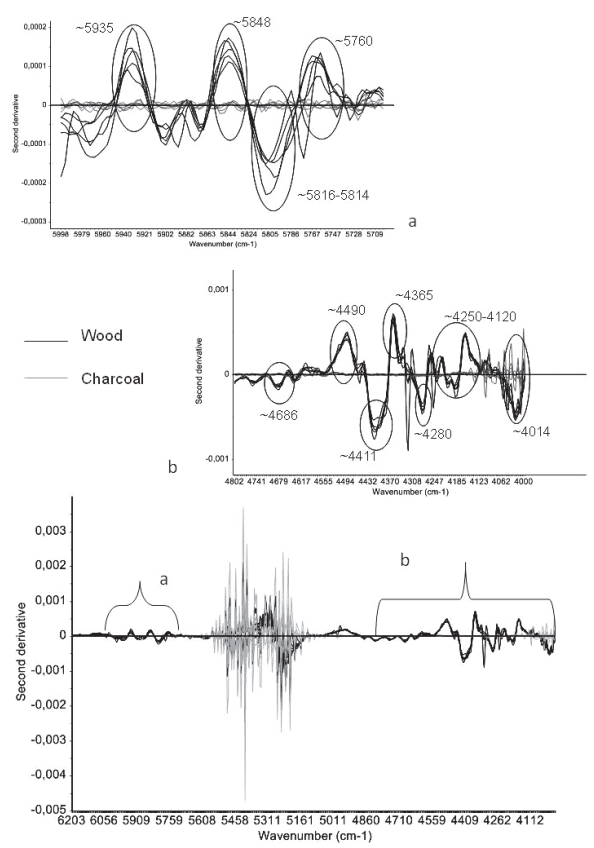

Figure 3. Second derivative of NIR spectra of wood and charcoal samples of "angelim" species. 
Chemical and anatomical composition of species results in different NIR absorbance values, and for discrimination some regions can have more influence. A spectral range from $4249-6100 \mathrm{~cm}^{-1}$ was efficient in distinguishing wood species similar to mahogany (Pastore et al. 2011) and 4000-6200 $\mathrm{cm}^{-1}$ showed potential in discriminating six origins of Criptomeria japonica planted in southern Brazil (Nisgoski et al. 2016). In this study with "angelim" species, regions with influence of water content were eliminated, and comparing wood and charcoal, two regions presented some differences, from 6200 to $5500 \mathrm{~cm}^{-1}$ (Figure 3a) and from 5000 to $4000 \mathrm{~cm}^{-1}$ (Figure 3b).

In wood samples, Vatairea guianensis presented peaks with stronger intensities at $4320 \mathrm{~cm}^{-1}$ and $4251 \mathrm{~cm}^{-1}$, which are related to cellulose groups. In the comparison of wood and charcoal spectra, some contrast was observed in bands that represent cell wall components, as expected, revealing the differences in chemical composition and thermal degradation: peaks at $\sim 5935 \mathrm{~cm}^{-1}, \sim 4411 \mathrm{~cm}^{-1}, \sim 4280$ $\mathrm{cm}^{-1}$ and $4014 \mathrm{~cm}^{-1}$, related to lignin; peaks at $\sim 5848 \mathrm{~cm}^{-1}, \sim 4686 \mathrm{~cm}^{-1}$, related to hemicelluloses; and peaks at $\sim 5760 \mathrm{~cm}^{-1}, \sim 4365 \mathrm{~cm}^{-1}, \sim 4252 \mathrm{~cm}^{-1}$, related to cellulose, are more distinct in wood samples.

Degrees of degradation based on the same carbonization process are species related (Muñiz et al. 2013). Each of the three major components of wood has its own characteristic properties related to thermal degradation, based on polymer composition. Thus, behavior is different if the components are isolated or combined in the wood cell matrix (Popescu et al. 2011). Between $30-250{ }^{\circ} \mathrm{C}$, no large changes were observed in the nanostructure of cellulose microfibrils, while between $250-315{ }^{\circ} \mathrm{C}$ the structure of cellulose fibrils were completely degraded and significant weight loss was observed. Between $315-1200{ }^{\circ} \mathrm{C}$, nanometer-sized inhomogeneities in the pyrolyzed wood samples appeared (Smith et al. 2012).

PCA was carried out to verify the distribution of samples from wood and charcoal with original data, Savitzky-Golay second derivative and MSC (Figure 4). For wood, the PCA graphs by species showed separation of spectra into two groups, in function of anatomical sections: group one from transversal section, group two from longitudinal sections (radial and tangential) for original data and pretreated with MSC. In second derivative, spectra distribution was more homogeneous and nonsection separation was observed, resulting in the best discrimination of "angelim" species in total analysis of wood species.

For charcoal, the PCA graphs by species revealed a distinction of groups by section, but after pretreatment by second derivative and MSC, just a tendency remained. Also for charcoal, the best discrimination of "angelim" species was observed with second derivative.

There are variations among species in NIR absorbance values, and for their discrimination, some regions can have more influence based on chemical and anatomical characteristics. Measurements taken at different points of a given sample can produce variations, but still allow distinction from other samples (Brunner et al. 1996). In species discrimination, second derivative pre-processing has also been applied in other studies (Sandak et al. 2011, Zhang et al. 2014). 

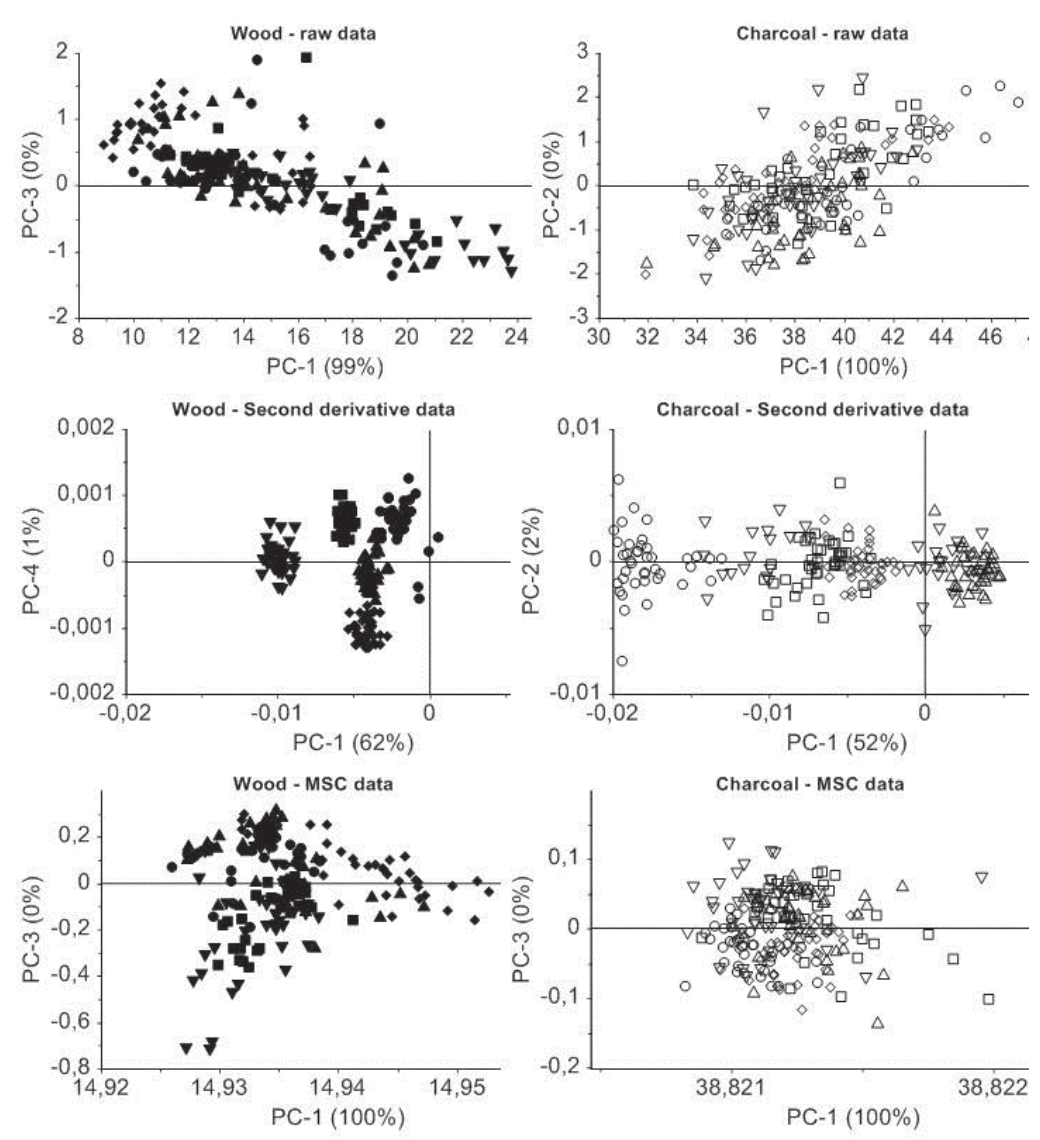

$\nabla$ Diplotropis purpurea

$\Delta$ Hymenolobium petraeum

$\diamond$ Parkia pendula

0 vatairea guianensis

$\square$ Vatairea paraensis

Figure 4. PCA score graph of wood and charcoal of "angelim" species with different pretreatments.

Classification of test samples by SIMCA (Tables 2-3) and PCA-LDA (Tables 4-5) was done based on the original spectra and pretreatments using second derivative and multiplicative scatter correction (MSC). We also compared all spectra and regions between $4000-5000 \mathrm{~cm}^{-1}$ plus $5500-6200 \mathrm{~cm}^{-1}$. In SIMCA classification, there was an overlapping classification, resulting in some samples not being uniquely classified, so that some individual samples may have been classified to two or more species. Each species therefore has both its right and wrong number of classified samples presented in the tables.

For SIMCA classification (Table 2), only the second derivatives of data from Diplotropis purpurea wood were correctly classified both with all spectra and region from $4000-5000 \mathrm{~cm}^{-1}$ plus $5500-6200$ $\mathrm{cm}^{-1}$. Misclassifications occurred for all other species, meaning that the analysis returned more than one species for each spectrum. Individual spectra not classified or with wrong response were almost all from transversal sections. This can be the result of the point where the spectra were obtained was performed (in a vessel, parenchyma, fiber or ray cell). In anatomical analysis, transversal sections bring more information about cell type and distribution, but chemical composition can be very similar. Also, surface irregularities might have influenced the results (Brunner et al. 1996), since the samples were 
only sawed.

For charcoal (Table 3), SIMCA classification was only $75 \%$ efficient for Vatairea guianensis with second derivative pretreatment, for all spectra and the region between $4000-5000 \mathrm{~cm}^{-1}$ plus $5500-6200$ $\mathrm{cm}^{-1}$. This result is related to different degradation of species.

Table 2. SIMCA classification of wood samples.

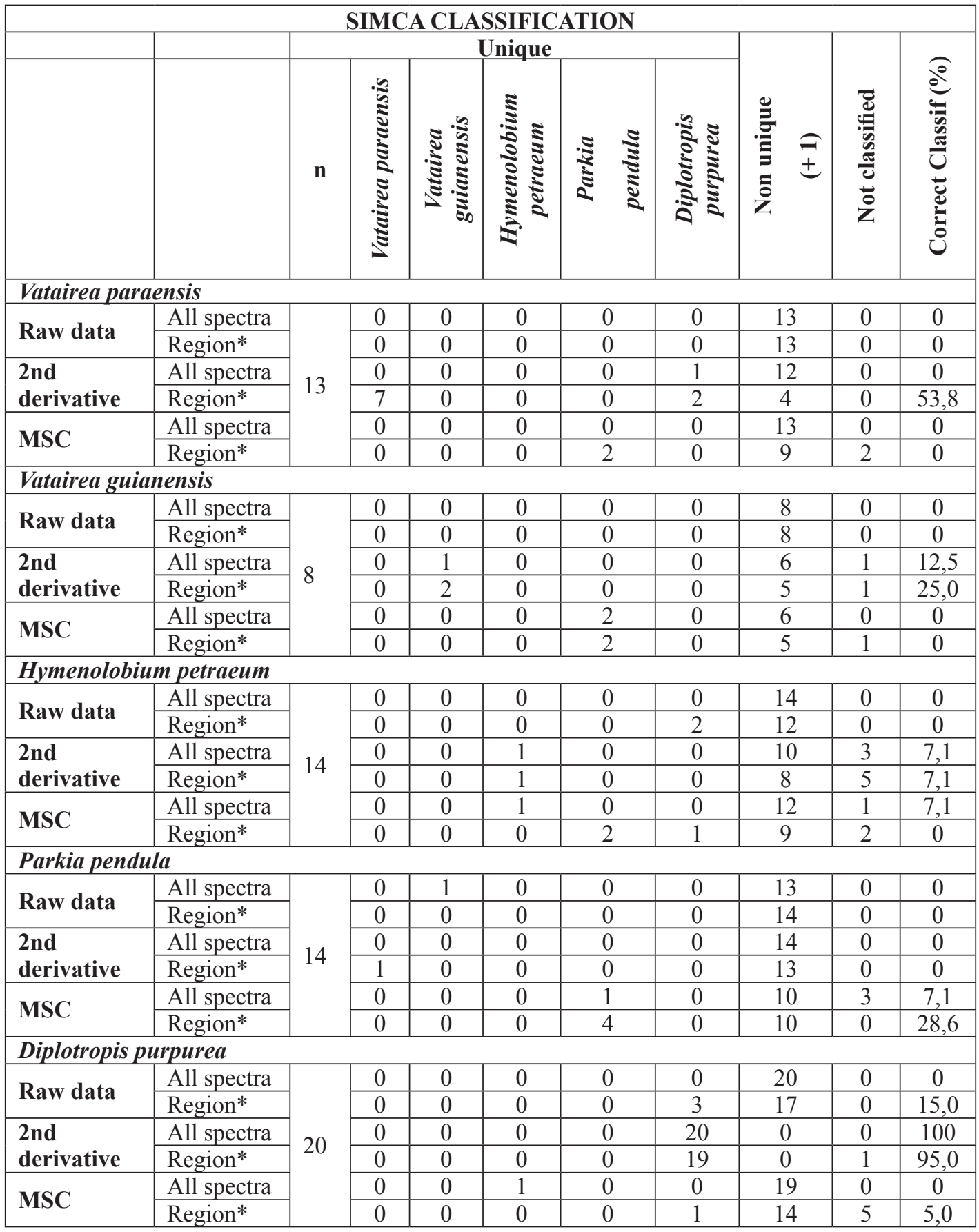

* Region between $4000-5000 \mathrm{~cm}^{-1}$ plus $5500-6200 \mathrm{~cm}^{-1}$. 
Table 3. SIMCA classification of charcoal samples.

\begin{tabular}{|c|c|c|c|c|c|c|c|c|c|c|c|}
\hline \multicolumn{12}{|c|}{ SIMCA CLASSIFICATION } \\
\hline & & \multicolumn{7}{|c|}{ Unique } & \multirow[b]{2}{*}{ 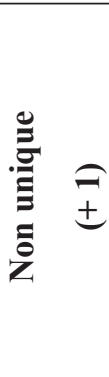 } & \multirow[b]{2}{*}{ 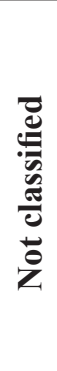 } & \multirow[b]{2}{*}{ 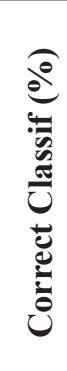 } \\
\hline & & $\mathbf{n}$ & 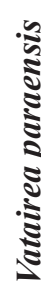 & 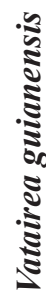 & 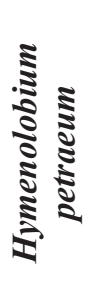 & $\underset{2}{\frac{\pi}{3}}$ & 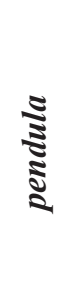 & 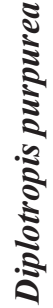 & & & \\
\hline \multicolumn{12}{|c|}{ Vatairea paraensis } \\
\hline \multirow{2}{*}{ Raw data } & All spectra & \multirow{6}{*}{13} & 0 & 0 & 0 & ( & j & 0 & 13 & 0 & 0 \\
\hline & Region* & & 0 & 0 & 0 & ( & j & 0 & 13 & 0 & 0 \\
\hline \multirow{2}{*}{$\begin{array}{l}\text { 2nd } \\
\text { derivative }\end{array}$} & All spectra & & 0 & 0 & 0 & ( & 5 & 0 & 13 & 0 & 0 \\
\hline & Region* & & 0 & 0 & 0 & ( & jo & 0 & 13 & 0 & 0 \\
\hline \multirow{2}{*}{ MSC } & All spectra & & 0 & 0 & 0 & ( & 5 & 0 & 11 & 2 & 0 \\
\hline & Region* & & 0 & 0 & 0 & ( & 5 & 0 & 11 & 2 & 0 \\
\hline \multicolumn{12}{|c|}{ Vatairea guianensis } \\
\hline \multirow{2}{*}{ Raw data } & All spectra & \multirow{6}{*}{8} & 0 & 2 & 0 & ( & j & 0 & 6 & 0 & 25,0 \\
\hline & Region* & & 0 & 0 & 0 & ( & jo & 0 & 8 & 0 & 0 \\
\hline \multirow{2}{*}{$\begin{array}{l}\text { 2nd } \\
\text { derivative }\end{array}$} & All spectra & & 0 & 6 & 0 & ( & 5 & 0 & 2 & 0 & 75,0 \\
\hline & Region* & & 0 & 6 & 0 & ( & 5 & 0 & 2 & 0 & 75,0 \\
\hline \multirow{2}{*}{ MSC } & All spectra & & 0 & 0 & 0 & ( & j & 0 & 7 & 1 & 0 \\
\hline & Region* & & 0 & 0 & 0 & ( & 5 & 0 & 7 & 1 & 0 \\
\hline \multicolumn{12}{|c|}{ Hymenolobium petraeum } \\
\hline \multirow{2}{*}{ Raw data } & All spectra & \multirow{6}{*}{14} & 1 & 0 & 0 & ( & j & 0 & 12 & 1 & 0 \\
\hline & Region* & & 0 & 0 & 0 & ( & 5 & 0 & 12 & 2 & 0 \\
\hline \multirow{2}{*}{$\begin{array}{l}\text { 2nd } \\
\text { derivative }\end{array}$} & All spectra & & 0 & 0 & 0 & ( & 5 & 0 & 14 & 0 & 0 \\
\hline & Region* & & 0 & 0 & 0 & ( & 5 & 0 & 14 & 0 & 0 \\
\hline \multirow{2}{*}{ MSC } & All spectra & & 0 & 0 & 0 & ( & 5 & 0 & 13 & 1 & 0 \\
\hline & Region* & & 0 & 0 & 0 & ( & jo & 0 & 13 & 1 & 0 \\
\hline \multicolumn{12}{|c|}{ Parkia pendula } \\
\hline \multirow{2}{*}{ Raw data } & All spectra & & 0 & 0 & 0 & ( & j & 0 & 14 & 0 & 0 \\
\hline & Region* & & 0 & 0 & 0 & ( & j & 0 & 14 & 0 & 0 \\
\hline 2nd & All spectra & 14 & 0 & 0 & 0 & ( & j & 0 & 14 & 0 & 0 \\
\hline derivative & Region* & 14 & 0 & 0 & 0 & ( & 5 & 0 & 14 & 0 & 0 \\
\hline MSC & All spectra & & 0 & 0 & 0 & ( & 5 & 0 & 14 & 0 & 0 \\
\hline MISC & Region* & & 0 & 0 & 0 & ( & 5 & 0 & 14 & 0 & 0 \\
\hline Diplotropis & rpurea & & & & & & & & & & \\
\hline Doru dlat & All spectra & & 0 & 0 & 0 & ( & j & 0 & 20 & 0 & 0 \\
\hline Raw data & Region* & & 0 & 0 & 0 & ( & 5 & 0 & 20 & 0 & 0 \\
\hline & All spectra & 0 & 0 & 0 & 0 & ( & jo & 0 & 20 & 0 & 0 \\
\hline derivative & Region* & 20 & 0 & 0 & 0 & ( & 5 & 0 & 20 & 0 & 0 \\
\hline $\operatorname{MCC}$ & All spectra & & 0 & 0 & 0 & ( & 5 & 0 & 20 & 0 & 0 \\
\hline IISC & Region* & & 0 & 0 & 0 & ( & 5 & 2 & 18 & 0 & 10,0 \\
\hline
\end{tabular}

* Region between $4000-5000 \mathrm{~cm}^{-1}$ plus $5500-6200 \mathrm{~cm}^{-1}$. 
The potential of FT-NIR spectra to classify wood was demonstrated with raw data (Brunner et al. 1996) and total spectra with Mahalanobis generalized distance (Tsuchikawa et al. 2003). In other studies, SIMCA classification was efficient to distinguish thermally modified wood of spruce, beech and ash (Bächle et al. 2012) and to separate red oak and white oak wood (Adedipe et al. 2008).

PCA-LDA showed better results in "angelim" species discrimination. For wood (Table 4), samples of Vatairea paraensis, Vatairea guianensis, Parkia pendula and Diplotropis purpurea presented 100\% correct classification with second derivative data and all spectra. For Vatairea paraensis and Diplotropis purpurea, the region between $4000-5000 \mathrm{~cm}^{-1}$ plus $5500-6200 \mathrm{~cm}^{-1}$ presented the same result. For charcoal (Table 5), PCA-LDA resulted in 100\% correct classification for Vatairea guianensis (second derivative, all spectra and region between $4000-5000 \mathrm{~cm}^{-1}$ plus 5500-6200 $\mathrm{cm}^{-1}$ ), Hymenolobium petraeum (region with raw data and second derivative), Parkia pendula (region with raw data and MSC) and Diplotropis purpurea (raw data with all spectra; region with raw data, second derivative and MSC). In these results, the region between $4000-5000 \mathrm{~cm}^{-1}$ plus $5500-6200 \mathrm{~cm}^{-1}$ presented more influence for correct classification and is related to species degradation in the same carbonization process.

The better results for region is because we eliminated the influence of water bands and the chemical differences remained based on cell wall distribution and composition or degradation, in the case of charcoal. PCA-LDA focuses on differences between species, and the natural variation of anatomical structure and chemical composition of "angelim" species, including the sections analyzed, resulted in more complete characterization of each sample, making the method more informative and robust. 
Table 4. PCA-LDA classification of wood samples.

\begin{tabular}{|c|c|c|c|c|c|c|c|c|c|c|c|c|}
\hline \multicolumn{13}{|c|}{ PCA-LDA CLASSIFICATION } \\
\hline & & \multicolumn{7}{|c|}{ Unique } & \multirow[b]{2}{*}{ 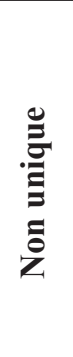 } & \multirow[b]{2}{*}{$\underset{ \pm}{ \pm}$} & \multirow[b]{2}{*}{ 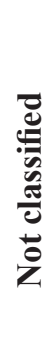 } & \multirow[b]{2}{*}{ 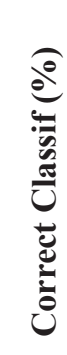 } \\
\hline & & n & 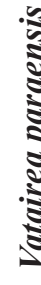 & 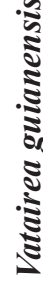 & 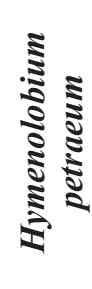 & 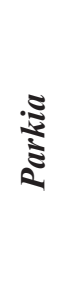 & \begin{tabular}{l}
\multirow{\Xi}{\Xi}{} \\
$\vdots$ \\
$\Xi$ \\
$\Xi$
\end{tabular} & 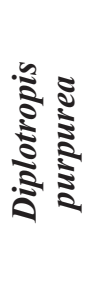 & & & & \\
\hline \multicolumn{13}{|c|}{ Vatairea paraensis } \\
\hline \multirow{2}{*}{ Raw data } & All spectra & \multirow{6}{*}{13} & 6 & 0 & 1 & c & 0 & 6 & 0 & & 0 & 46,1 \\
\hline & Region* & & 6 & 0 & 1 & c & 0 & 6 & 0 & & 0 & 46,1 \\
\hline \multirow{2}{*}{$\begin{array}{l}\text { 2nd } \\
\text { derivative }\end{array}$} & All spectra & & 13 & 0 & 0 & c & 0 & 0 & 0 & & 0 & 100 \\
\hline & Region* & & 13 & 0 & 0 & $\mathrm{c}$ & 0 & 0 & 0 & & 0 & 100 \\
\hline \multirow{2}{*}{ MSC } & All spectra & & 4 & 0 & 1 & c & 0 & 8 & 0 & 5 & 0 & 30,8 \\
\hline & Region* & & 6 & 0 & 0 & $\mathrm{C}$ & 0 & 7 & 0 & ) & 0 & 46,1 \\
\hline \multicolumn{13}{|c|}{ Vatairea guianensis } \\
\hline \multirow{2}{*}{ Raw data } & All spectra & \multirow{6}{*}{8} & 2 & 1 & 0 & 2 & 2 & 3 & 0 & 5 & 0 & 12,5 \\
\hline & Region* & & 0 & 5 & 0 & 2 & 2 & 1 & 0 & j & 0 & 62,5 \\
\hline \multirow{2}{*}{$\begin{array}{l}\text { 2nd } \\
\text { derivative }\end{array}$} & All spectra & & 0 & 8 & 0 & c & 0 & 0 & 0 & & 0 & 100 \\
\hline & Region* & & 0 & 7 & 1 & c & 0 & 0 & 0 & & 0 & 87,5 \\
\hline \multirow{2}{*}{ MSC } & All spectra & & 0 & 1 & 4 & & 1 & 2 & 0 & 5 & 0 & 12,5 \\
\hline & Region* & & 1 & 2 & 4 & & 0 & 1 & 0 & & 0 & 25,0 \\
\hline \multicolumn{13}{|c|}{ Hymenolobium petraeum } \\
\hline \multirow{2}{*}{ Raw data } & All spectra & \multirow{6}{*}{14} & 6 & 2 & 0 & & 0 & 6 & 0 & & 0 & 0 \\
\hline & Region* & & 1 & 3 & 5 & & 1 & 4 & 0 & & 0 & 35,7 \\
\hline \multirow{2}{*}{$\begin{array}{l}\text { 2nd } \\
\text { derivative }\end{array}$} & All spectra & & 0 & 4 & 10 & & 0 & 0 & 0 & & 0 & 71,4 \\
\hline & Region* & & 0 & 3 & 11 & & 0 & 0 & 0 & & 0 & 78,6 \\
\hline \multirow{2}{*}{ MSC } & All spectra & & 2 & 2 & 10 & & 0 & 0 & 0 & & 0 & 71,4 \\
\hline & Region* & & 1 & 2 & 8 & 2 & 2 & 1 & 0 & & 0 & 57,1 \\
\hline \multicolumn{13}{|c|}{ Parkia pendula } \\
\hline \multirow{2}{*}{ Raw data } & All spectra & & 4 & 1 & 2 & & 7 & 0 & 0 & & 0 & 50,0 \\
\hline & Region* & & 0 & 2 & 1 & 1 & 11 & 0 & 0 & & 0 & 78,6 \\
\hline \multirow{2}{*}{$\begin{array}{l}\text { 2nd } \\
\text { derivative }\end{array}$} & All spectra & & 0 & 0 & 0 & & 4 & 0 & 0 & & 0 & 100 \\
\hline & Region* & 14 & 7 & 0 & 0 & & 7 & 0 & 0 & & 0 & 50,0 \\
\hline MSC & All spectra & & 0 & 0 & 4 & & 0 & 0 & 0 & & 0 & 71,4 \\
\hline VISC & Region* & & 1 & 0 & 5 & 8 & 8 & 0 & 0 & & 0 & 57,1 \\
\hline Diplotropis & rpurea & & & & & & & & & & & \\
\hline & All spectra & & 6 & 1 & 3 & & 1 & 9 & 0 & & 0 & 45,0 \\
\hline Raw data & Region* & & 3 & 0 & 0 & $\mathrm{C}$ & 0 & 17 & 0 & & 0 & 85,0 \\
\hline & All spectra & & 0 & 0 & 0 & $\mathrm{C}$ & 0 & 20 & 0 & & 0 & 100 \\
\hline derivative & Region* & 20 & 0 & 0 & 0 & $\mathrm{C}$ & 0 & 20 & 0 & & 0 & 100 \\
\hline & All spectra & & 3 & 0 & 0 & $\mathrm{c}$ & 0 & 17 & 0 & & 0 & 85,0 \\
\hline MSC & Region* & & 2 & 0 & 0 & 0 & 0 & 18 & 0 & & 0 & 90,0 \\
\hline
\end{tabular}

* Region between $4000-5000 \mathrm{~cm}^{-1}$ plus $5500-6200 \mathrm{~cm}^{-1}$. 
Table 5. PCA-LDA classification of charcoal samples.

\begin{tabular}{|c|c|c|c|c|c|c|c|c|c|c|c|c|}
\hline \multicolumn{13}{|c|}{ PCA-LDA CLASSIFICATION } \\
\hline & & \multicolumn{7}{|c|}{ Unique } & \multirow[b]{2}{*}{ 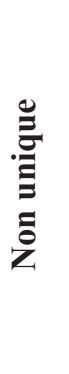 } & \multirow[b]{2}{*}{$\stackrel{\overbrace{}}{ \pm}$} & \multirow[b]{2}{*}{ 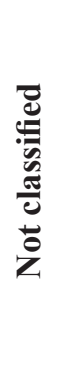 } & \multirow[b]{2}{*}{ 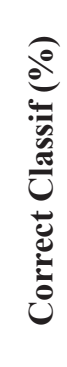 } \\
\hline & & n & $\begin{array}{l}0 \\
5 \\
3 \\
3\end{array}$ & 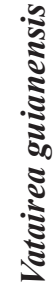 & 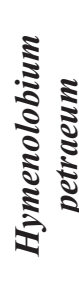 & 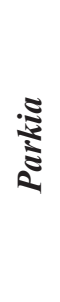 & $\begin{array}{l}\frac{\Xi}{3} \\
\vdots \\
\vdots \\
\vdots \\
\vdots\end{array}$ & 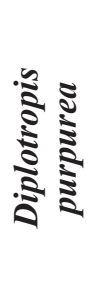 & & & & \\
\hline \multicolumn{13}{|c|}{ Vatairea paraensis } \\
\hline \multirow{2}{*}{ Raw data } & All spectra & \multirow{6}{*}{13} & 7 & 0 & 6 & ( & $\overline{0}$ & 0 & 0 & & 0 & 53,8 \\
\hline & Region* & & 11 & 0 & 0 & ( & 0 & 2 & 0 & & 0 & 84,6 \\
\hline \multirow{2}{*}{$\begin{array}{l}\text { 2nd } \\
\text { derivative }\end{array}$} & All spectra & & 9 & 0 & 0 & ( & 0 & 4 & 0 & & 0 & 69,2 \\
\hline & Region* & & 12 & 0 & 0 & ( & 0 & 1 & 0 & & 0 & 92,3 \\
\hline \multirow{2}{*}{ MSC } & All spectra & & 9 & 0 & 0 & ( & 0 & 4 & 0 & & 0 & 69,2 \\
\hline & Region* & & 12 & 0 & 0 & ( & 0 & 1 & 0 & & 0 & 92,3 \\
\hline \multicolumn{13}{|c|}{ Vatairea guianensis } \\
\hline \multirow{2}{*}{ Raw data } & All spectra & \multirow{6}{*}{8} & 1 & 6 & 0 & ( & 0 & 1 & 0 & & 0 & 75,0 \\
\hline & Region* & & 0 & 7 & 0 & ( & 0 & 1 & 0 & & 0 & 87,5 \\
\hline \multirow{2}{*}{$\begin{array}{l}\text { 2nd } \\
\text { derivative }\end{array}$} & All spectra & & 0 & 8 & 0 & ( & 0 & 0 & 0 & & 0 & 100 \\
\hline & Region* & & 0 & 8 & 0 & ( & 0 & 0 & 0 & & 0 & 100 \\
\hline \multirow{2}{*}{ MSC } & All spectra & & 0 & 7 & 0 & 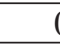 & 0 & 1 & 0 & & 0 & 87,5 \\
\hline & Region* & & 0 & 8 & 0 & ( & 0 & 0 & 0 & & 0 & 100 \\
\hline \multicolumn{13}{|c|}{ Hymenolobium petraeum } \\
\hline \multirow{2}{*}{ Raw data } & All spectra & \multirow{6}{*}{14} & 4 & 0 & 7 & . & 1 & 2 & 0 & & 0 & 50,0 \\
\hline & Region* & & 0 & 0 & 14 & ( & 0 & 0 & 0 & & 0 & 100 \\
\hline \multirow{2}{*}{$\begin{array}{l}\text { 2nd } \\
\text { derivative }\end{array}$} & All spectra & & 0 & 0 & 11 & 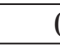 & 0 & 3 & 0 & & 0 & 78,6 \\
\hline & Region* & & 0 & 0 & 14 & ( & 0 & 0 & 0 & & 0 & 100 \\
\hline \multirow{2}{*}{ MSC } & All spectra & & 0 & 0 & 13 & ( & 0 & 1 & 0 & & 0 & 92,8 \\
\hline & Region* & & 0 & 8 & 13 & 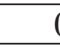 & 0 & 1 & 0 & & 0 & 92,8 \\
\hline \multicolumn{13}{|c|}{ Parkia pendula } \\
\hline Raw data & All spectra & & 1 & 0 & 5 & $\varepsilon$ & 8 & 0 & 0 & & 0 & 57,1 \\
\hline Raw data & Region* & & 0 & 0 & 0 & 1 & 4 & 0 & 0 & & 0 & 100 \\
\hline & All spectra & 14 & 5 & 0 & 0 & 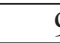 & 9 & 0 & 0 & & 0 & 64,3 \\
\hline derivative & Region* & 14 & 4 & 0 & 0 & & 0 & 0 & 0 & & 0 & 71,4 \\
\hline MSC & All spectra & & 3 & 0 & 0 & & 11 & 0 & 0 & & 0 & 78,6 \\
\hline MISC & Region* & & 0 & 0 & 0 & & 4 & 0 & 0 & & 0 & 100 \\
\hline Diplotropis & rpurea & & & & & & & & & & & \\
\hline Raw data & All spectra & & 0 & 0 & 0 & & 0 & 20 & 0 & & 0 & 100 \\
\hline Kaw data & Region* & & 0 & 0 & 0 & ( & 0 & 20 & 0 & & 0 & 100 \\
\hline & All spectra & 20 & 1 & 0 & 11 & 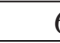 & 6 & 2 & 0 & & 0 & 10,0 \\
\hline derivative & Region* & 20 & 0 & 0 & 0 & ( & 0 & 20 & 0 & & 0 & 100 \\
\hline MSC & All spectra & & 2 & 0 & 3 & ( & 0 & 15 & 0 & & 0 & 75,0 \\
\hline MISC & Region* & & 0 & 0 & 0 & & 0 & 20 & 0 & & 0 & 100 \\
\hline
\end{tabular}

* Region between $4000-5000 \mathrm{~cm}^{-1}$ plus $5500-6200 \mathrm{~cm}^{-1}$. 
Data pre-processing influenced the results, which were different for wood and charcoal samples of "angelim" species (Table 6). For solid wood, the best performance was with second derivative, and for solid charcoal, MSC presented the highest percentage of correct classification. SIMCA was not efficient for "angelim" species discrimination. PCA-LDA presented the best results and the use of the region between $4000-5000 \mathrm{~cm}^{-1}$ plus $5500-6200 \mathrm{~cm}^{-1}$ was more suitable. These results show the influence of sample characteristics (surface direction and irregularities) and carbonization process.

Table 6. Total correct classification of wood and charcoal samples of five "angelim" species.

\begin{tabular}{|llcccc|}
\hline $\begin{array}{c}\text { Classification } \\
\text { method }\end{array}$ & Pretreatment & \multicolumn{2}{c}{$\begin{array}{c}\text { Correct classification of } \\
\text { wood samples (\%) }\end{array}$} & \multicolumn{2}{c|}{$\begin{array}{c}\text { Correct classification of } \\
\text { charcoal samples (\%) }\end{array}$} \\
& All & $4000-5000+$ & All & $4000-5000+5500-$ \\
spectra & $5500-6200 \mathrm{~cm}^{-1}$ & spectra & $6200 \mathrm{~cm}^{-1}$ \\
\hline SIMCA & Raw & 0 & 4 & 3 & 0 \\
& $2^{\text {nd }}$ derivative & 33 & 42 & 9 & 6 \\
\multirow{3}{*}{ PCA-LDA } & MSC & 3 & 7 & 0 & 2 \\
& Raw & 33 & 64 & 84 & 96 \\
& $2^{\text {nd }}$ derivative & 94 & 84 & 56 & 93 \\
& MSC & 61 & 61 & 80 & 97 \\
\hline
\end{tabular}

In studies with solid wood samples, a higher number of samples was found to be better to establish distributions, because wood surface (Braga et al. 2011), shape and particle size (Nisgoski et al. 2015a) can have a significant influence on species discrimination by NIR. Only based on PCA graphs, Nisgoski et al. (2015b) obtained results adequate for wood discrimination of two species of Euphorbiaceae and two species of Moraceae, but for charcoal only the family could be distinguished.

In this study with "angelim" species, the number of test samples was small but the objective was achieved and the potential of near infrared application with solid samples for distinction of wood and charcoal as demonstrated. 


\section{CONCLUSIONS}

The results of anatomical analysis showed that the qualitative characteristics of wood remained in charcoal and can be applied for species discrimination. In function of natural variation of species characteristics, charcoal must be compared with reference material collections. When comparing cell dimensions, we observed different behavior between species in the same carbonization process in function of cell wall thickness and parenchyma distribution.

In infrared analysis, the results were influenced by the section where the spectra were collected, the pretreatment was applied, classification method and spectrum region analyzed. The distribution of spectra from each species' transversal section was distinct from the spectral distributions of the radial and tangential sections when raw data were analyzed. Second derivative eliminated this distinction and resulted in the best discrimination of "angelim" species.

SIMCA classification was not adequate for these species' discrimination based on wood and charcoal. PCA-LDA was more efficient and reached more than $90 \%$ correct classification. Bands with influence of water must be eliminated and the region between $4000-5000$ plus $5500-6200 \mathrm{~cm}^{-1}$ was more efficient for "angelim" species discrimination.

For rapid analysis for forest control or detection of illegal commerce, spectra collected directly from wood and charcoal can be used to distinguish of species sold as "angelim".

\section{REFERENCES}

Adedipe, O.E.; Dawsin-Andoh, A.B.; Slahor, J.; Osborn, A.L. 2008. Classification of red oak (Quercus rubra) and white oak (Quercus alba) wood using a near infrared spectrometer and soft independent modelling of class analogies. Journal of Near Infrared Spectroscopy 16(1):49-57.

American Society for Testing and Materials. 2000. Standard practices for infrared multivariate, quantitative analysis. ASTM E1655. Vol.03.06. West Conshohocken, Pennsylvania, USA.

Bächle, H.; Zimmer, B.; Wegener, G. 2012. Classification of thermally modified wood by FTNIR spectroscopy and SIMCA. Wood Science and Technology 46(6):1181-1192.

Braga, J.W.B.; Pastore, T.C.M.; Coradin, V.T.R.; Camargos, J.A.A.; Silva, A.R.D. 2011. The use of near infrared spectroscopy to identify solid wood specimens of Swietenia macrophylla (cites appendix II). IAWA Journal 32(2):285-296.

Brunner, M.; Eugster, R.; Trenka, E.; Bergamin-Strotz, L. 1996. FT-NIR spectroscopy and wood identification. Holzforschung 50(2):130-134.

Bylesjo, M.; Rantalainen, M.; Cloarec, O.; Nicholson, J.K.; Holmes, E.; Trygg, J. 2006. OPLS discriminant analysis: combining the strengths of PLS-DA and SIMCA classification. Journal of Chemometrics 20(8-10):341-351.

Carneiro, M.E.; Magalhães, W.L.E.; Nisgoski, S.; Muñiz, G.I.B. 2013. Classification of Pinus spp. veneers wood contaminated by blue stain fungi. Revista Arvore 37(2):369-375. 
Casale, M.; Schimleck, L.R.; Espeyd, C. 2010. Classification of pernambuco (Caesalpinia echinata Lam.) wood quality by near infrared spectroscopy and linear discriminant analysis. Journal of Near Infrared Spectroscopy 18(6):435-442.

Ciosek, P.; Brzozka, Z.; Wroblewski, W.; Martinelli, E.; Di Natale, C.; D’Amico, A. 2005. Direct and two-stage data analysis procedures based on PCA, PLS-DA and ANN for ISE-based electronic tongue - effect of supervised feature extraction. Talanta 67: 590-596.

Davrieux, F. ; Rousset, P.L.A.; Pastore, T.C.M.; Macedo, L.A.; Quirino, W.F. 2010. Discrimination of native wood charcoal by infrared spectroscopy. Química Nova 33(5):1093-1097.

Ferreira, G.C.; Gomes, J.I.; Hopkins, M.J.G. 2004. An anatomic study of Leguminosae species in the state of Pará commercialized as "angelim". Acta Amazonica 34(3):387-398.

Gasson, P. 2011. How precise can wood identification be? Wood Anatomy's role in support of the legal timber trade, especially CITES. IAWA Journal 32(2):137-154.

Geladi, P.; McDougall, D.; Martens, H. 1985. Linearization and scatter-correction for nearinfrared reflectance spectra of meat. Applied Spectroscopy 39(3):491-500.

Gonçalves, T.A.P.; Marcati, C.R.; Scheel-Ybert, R. 2012. The effect of carbonization on wood structure of Dalbergia violaceae, Stryphnodendron polyphyllum, Tapirira guianensis, Vochysia tucanorum and Pouteria torta from the Brazilian cerrado. IAWA Journal 33(1):73-90.

Goncalves, T.A.P.; Ballarin, A.W.; Nisgoski, S.; Muniz, G.I.B. 2014. A contribution to the identification of charcoal origin in Brazil I - Anatomical characterization of Corymbia and Eucalyptus. Maderas-Cienc Tecnol 16(30):323-336.

Hwang, S.W.; Horikawa, Y.; Lee, W.H.; Sugiyama, J. 2016. Identification of Pinus species related to historic architecture in Korea using NIR chemometric approaches. Journal of Wood Science 62:156-167.

IAWA.1989. List of microscopic features for hardwood identification. IAWA Bulletin 10(3):219332.

Martens, H.; Jensen, S. A.; Geladi, P. 1983. Nordic Symposium on Applied Statistics, Skagenkaien; Stokkand Forlag Publishing: CITY, 1983, pp 208-234.

Monteiro, T.C.; Silva, R.V.; Lima, J.T.; Hein, P.R.G.; Napoli, A. 2010. Use of near infrared spectroscopy to distinguish carbonization processes and charcoal sources. Cerne 16(3):381-390.

Muñiz, G.I.B.; Nisgoski, S.; França, R.F.; Schardosin, F.Z. 2012. Comparative anatomy of wood and charcoal of Cedrelinga catenaeformis Ducke and Enterolobium schomburgkii Benth. for identification purposes. Scientia Forestalis 40(94):291-297.

Muñiz, G.I.B.; Carneiro, M.E.; Nisgoski, S.; Ramirez, M.G.L.; Magalhães, W.L.E. 2013. SEM and NIR characterization of four charcoal species. Wood Science and Technology 47(4):815-823.

Nisgoski, S.; Carneiro, M.E.; Muñiz, G.I.B. 2015a. Influencia de la granulometría de la muestra en la discriminación de especies de Salix por infrarrojo cercano. Maderas-Cienc Tecnol 17(1):195-204.

Nisgoski, S.; Muñiz, G.I.B.; Morrone, S.R.; Schardosin, F.Z.; França, R.F. 2015b. NIR and anatomy of wood and charcoal from Moraceae and Euphorbiaceae species. Ciência da Madeira 6(3):183-190. 
Nisgoski, S.; Schardosin, F.Z.; Batista, F.R.R.; Muñiz, G.I.B.; Carneiro, M.E. 2016. Potential use of NIR spectroscopy to identify Cryptomeria japonica varieties from southern Brazil. Wood Science and Technology 50(1):71-80.

Pastore, T.C.M.; Braga, J.W.B.; Coradin, V.T.R.; Magalhães, W.L.E.; Okino, E.Y.A.; Camargos, J.A.A.; De Muñiz, G.I.B.; Bressan, O.A.; Davrieux, F. 2011. Near infrared spectroscopy (NIRS) as a potential tool for monitoring trade of similar woods: discrimination of true magogany, cedar, andiroba and curupixá. Holzforschung 65(1):73-80.

Popescu, M.C.; Popescu, C.M.; Lisa, G.; Sakata, Y. 2011. Evaluation of morphological and chemical aspects of different wood species by spectroscopy and thermal methods. Journal of Molecular Structure 988:65-72.

Rinnan, A.; Van den Berg, F.; Engelsen, B. 2009. Review of the most common pre-processing techniques for near-infrared spectra. Trends in Analytical Chemistry 28(10): 1201-1222.

Russ, A.; Firesova, M.; Gigac, J. 2009. Preliminary study of wood species identification by NIR spectroscopy. Wood Research 54(4):23-32.

Sandak, A.; Sandak, J.; Negri, M. 2011. Relationship between near-infrared (NIR) spectra and the geographical provenance of timber. Wood Science and Technology 45(1):35-48.

Siesler, H.W.; Ozaki, Y.; Kawata, S.; Heise, M. 2002. Near infrared spectroscopy: principle, instrumentation and applications. Wiley-VCH Verlag GmbH, Weinheim, Germany.

Smith, A.J.; MacDonald, M.J.; Ellis, L.D.; Obrovac, M.N.; Dahn, J.R. 2012. A small angle X-ray scattering and electrochemical study of the decomposition of wood during pyrolysis. Carbon 50:3717-3723.

Soares, W.F.; Melo, L.E.L.; Lisboa, P.L.B. 2014. Anatomy of five wood species marketed as 'sucupira'. Floresta e Ambiente 21(1):114-125.

Schwanninger, M.; Rodrigues, J.C.; Fackler, K. 2011. A review of band assignments in near infrared spectra of wood and wood components. Journal of Near Infrared Spectroscopy 19:287-308.

Stumpe, B.; Engel, T.; Steinweg, B.; Marschner, B. 2012. Application of PCA and SIMCA statistical analysis of FT-IR spectra for the classification and identification of different slag types with environmental origin. Environmental Science and Technology 46(7):3964-3972.

Tominaga, Y. 1999. Comparative study of class data analysis with PCA-LDA, SIMCA, PLS, ANNs, and $k$-NN. Chemometrics and Inteliggent Laboratory Systems 49:105-115.

Tsuchikawa, S.; Inoue, K.; Noma, J.; Hayashi, K. 2003. Application of near-infrared spectroscopy to wood discrimination. Journal of Wood Science 49:29-35.

Tsuchikawa, S.; Schwanninger, M. 2013. A review of recent near-infrared research for wood and paper (Part 2). Applied Spectroscopy Reviews 48:560-587.

Tsuchikawa, S.; Siesler, H.W. 2003. Near-Infrared spectroscopy monitoring of the diffusion process of deuterium-labeled molecules in wood. Part I. Softwood. Applied Spectroscopy 57(6):667674.

Yonenobu, H.; Tsuchikawa, S. 2003. Near-Infrared spectroscopic comparison of antique and modern wood. Applied Spectroscopy 57(11):1451-1453. 
Zhang, X.; Yu, H.; Li, B.; Li, W.J.; Li, X.; Bao, C. 2014. Discrimination of Pinus yunnanensis, P. kesiya and P. densata by FT-NIR. Journal Chemical Pharmaceutical Resources 6(4):142-149. 